\title{
Pure sensory infarct in the territories of anterior cerebral artery
}

Figure 1 Sensory topography of the patient (solid area shows the region of sensory disturbance)
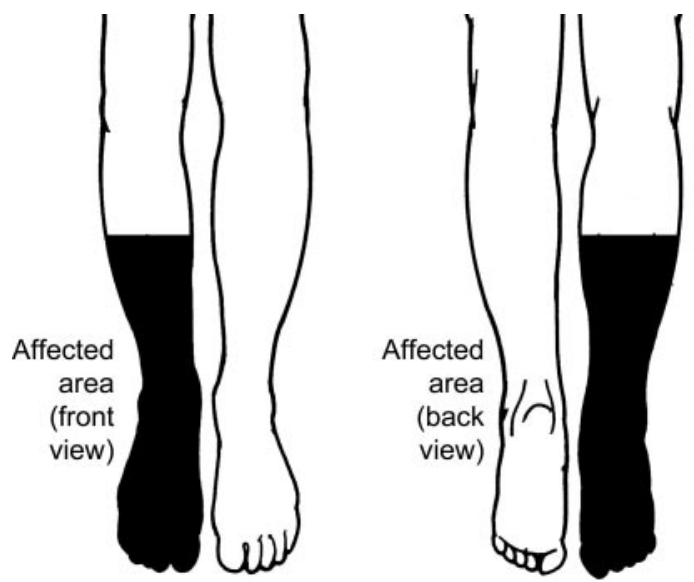

Figure 2 Fluid-attenuated inversion recovery sequences of brain MRI
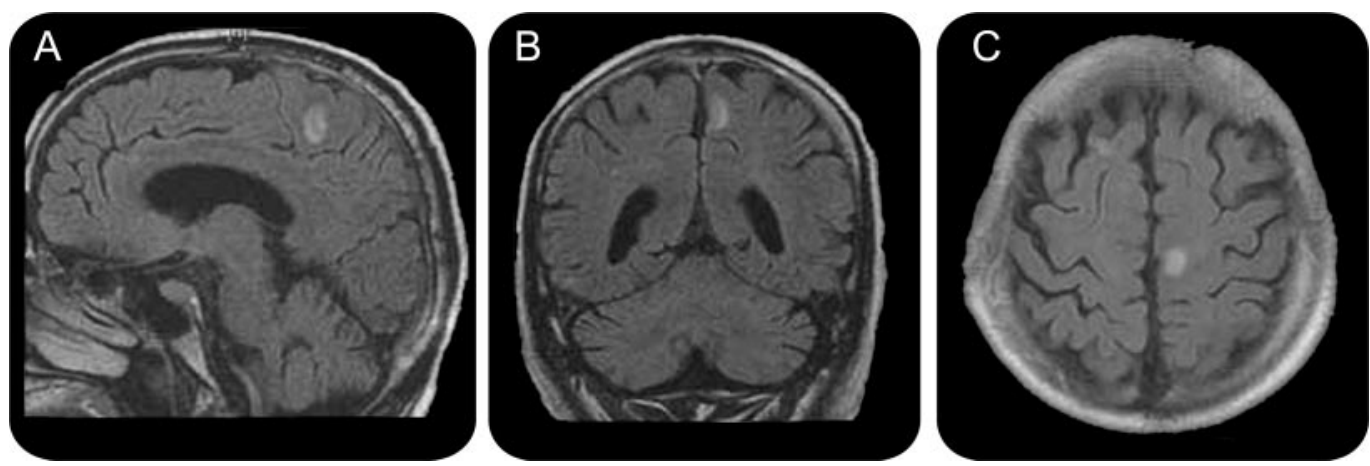

Sagittal (A), coronal (B), and axial (C) views show a hyperintense area in the left paracentral lobule in the territories of anterior cerebral artery.

A 78-year-old man suddenly developed tingling sensations and sensory loss involving all modalities only in his right foot, distal shin, and calf (figure 1). Brain MRI revealed a small acute infarct in the left paracentral lobule (figure 2). Many patients with pure sensory disturbance by cortical infarcts have been reported in the territories of middle cerebral artery. ${ }^{1}$ We report a pure sensory cortical infarct in the territories of anterior cerebral artery. These MRI pictures are exactly suggestive of anatomic cortical sensory area for distal lower limb, being consistent with the sensory homunculus. ${ }^{2}$

Yoichiro Nishida, MD, PhD, Takashi Irioka, MD, PhD, Terubiko Sekiguchi, MD, Hidehiro Mizusawa, MD, PhD, Tokyo, Japan

Disclosure: The authors report no disclosures.

Address correspondence and reprint requests to Dr. Yoichiro Nishida, Department of Neurology and Neurological Science, Graduate School, Tokyo Medical and Dental University, Yushima 1-5-45, Bunkyo-ku, Tokyo 113-8519, Japan; y-nishida.nuro@tmd.ac.jp

1. Kim JS. Patterns of sensory abnormality in cortical stroke: evidence for a dichotomized sensory system. Neurology 2007;68:174-180.

2. Penfield W, Boldrey E. Somatic motor and sensory representation in the cerebral cortex of man as studied by electrical stimulation. Brain 1937;60:389-443. 


\section{Neurology}

\section{Pure sensory infarct in the territories of anterior cerebral artery \\ Yoichiro Nishida, Takashi Irioka, Teruhiko Sekiguchi, et al. \\ Neurology 2010;75;287 \\ DOI 10.1212/WNL.0b013e3181e8e906}

\section{This information is current as of July 19, 2010}

\section{Updated Information \& Services}

References

Citations

Subspecialty Collections

Permissions \& Licensing

Reprints including high resolution figures, can be found at: http://n.neurology.org/content/75/3/287.full

This article cites 2 articles, 1 of which you can access for free at: http://n.neurology.org/content/75/3/287.full\#ref-list-1

This article has been cited by 1 HighWire-hosted articles: http://n.neurology.org/content/75/3/287.full\#\#otherarticles

This article, along with others on similar topics, appears in the following collection(s):

\section{Infarction}

http://n.neurology.org/cgi/collection/infarction

Information about reproducing this article in parts (figures,tables) or in its entirety can be found online at:

http://www.neurology.org/about/about_the_journal\#permissions

Information about ordering reprints can be found online:

http://n.neurology.org/subscribers/advertise

Neurology ${ }^{\circledR}$ is the official journal of the American Academy of Neurology. Published continuously since 1951, it is now a weekly with 48 issues per year. Copyright . All rights reserved. Print ISSN: 0028-3878. Online ISSN: 1526-632X.

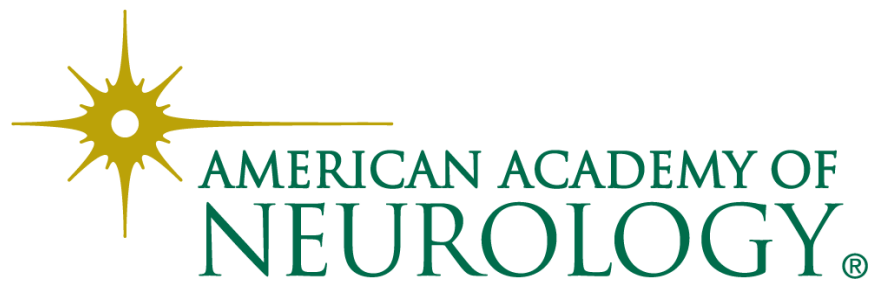

